\title{
Demand-side mitigation options of the agricultural sector: potential, barriers and ways forward
}

\author{
Thierry Brunelle ${ }^{1, *}$, Mathilde Coat $^{2}$ and Vincent Viguié ${ }^{3}$ \\ ${ }^{1}$ Cirad, UMR CIRED, 94736 Nogent-sur-Marne, France \\ 2 AgroParisTech, 75005 Paris, France \\ ${ }^{3}$ ENPC, UMR CIRED, 94736 Nogent-sur-Marne, France
}

Received 10 September 2016 - Accepted 28 November 2016

\begin{abstract}
This paper reviews the potential and barriers of demand-side mitigation options in the agricultural sector based on the recent academic literature and on a survey conducted on a sample of 788 respondents living in France. The mitigation potential of such measures as reducing losses in the food supply chain and shifting diets toward less animal products is estimated to be particularly high, higher, in particular, than supply-side mitigation options. However, to ensure that these measures do not entail a reduction in protein intake, these estimations should consider both caloric and protein units, and take into account the digestibility differentials between protein sources. Our survey shows that people are relatively reluctant to eat more sustainably, preferring to reduce their emissions in other areas such as housing or equipment. This relative reluctance is mainly due to individual perceptions linked to health concerns, taste or habits. Some obstacles could easily be overcome through well-designed policies aiming to, for example, advertise a lower consumption of red meat for health benefits. National governments are, however, rather inactive on this topic, leaving the initiative to the civil society.
\end{abstract}

Keywords: diet shift / mitigation of climate change / food waste / agriculture

Résumé - Atténuer le changement climatique par la réduction de la demande agricole : potentiel, barrières et mise en œuvre. Cet article passe en revue le potentiel d'atténuation et les barrières liés à la réduction de la demande agricole sur la base de la littérature académique récente et d'une enquête menée auprès de 788 personnes résidant en France. Le potentiel d'atténuation de mesures telles que la réduction des pertes dans la chaîne de production alimentaire ou la transition vers des régimes alimentaires moins carnés apparaît important selon les estimations disponibles, plus important, en particulier, que les options d'atténuation concernant l'offre agricole. Cependant, afin de garantir que ces mesures n'impliquent pas une réduction de la consommation de protéines, ces estimations devraient considérer à la fois les unités caloriques et protéiques, et tenir compte du différentiel de digestibilité entre les sources de protéines. Notre enquête montre que les gens sont relativement réticents à opter pour une alimentation plus durable, préférant réduire leurs émissions sur d'autres domaines tels que l'habitat ou l'équipement. Cette relative réticence s'explique principalement par des perceptions individuelles liées à la santé, au goût et aux habitudes. Certains obstacles pourraient facilement être surmontés par des politiques bien conçues visant, par exemple, à promouvoir les bénéfices pour la santé d'une réduction de la consommation de viande rouge. Les gouvernements nationaux restent cependant relativement inactifs sur ce sujet, préférant laisser l'initiative à la société civile.

Mots clés : transition alimentaire / atténuation du changement climatique / gaspillage alimentaire / agriculture

\section{Introduction}

As emphasized by Weber and Matthews (2008), "food represents a unique opportunity for consumers to lower their personal impacts due to its high impact, high degree of personal choice, and a lack of long-term "lock-in" effects

\footnotetext{
* Correspondence: thierry. brunelle@cirad.fr
}

which limit consumers' day-to-day choices"; yet, mitigation options relating to food consumption are almost taboo in international negotiations on climate and public policies. It is sometimes argued that mitigating climate change by reducing food consumption is a sensitive issue given the high rate of undernourishment in many regions of the world. Overconsumption of food, however, is becoming a serious public health issue that affects about one-third of the world population $(\mathrm{Ng}$ et al., 2014). Another dimension of this issue, which is less 
foregrounded, but probably just as significant, relates to the fact that restricting the consumption of such an item so intimately linked to individual choice as food is a delicate matter indeed in liberal societies.

Agriculture, Forestry and Other Land Use (AFOLU), the second largest greenhouse gases emitting sector after the industry sector (taking into account emissions from the heat and electricity production sector) (Smith et al., 2014), is characterized by a large mitigation potential. Many options for reducing greenhouse gas (GHG) emissions are available, such as the following: carbon storage through afforestation/ reforestation and bioenergy production, enhanced resource use efficiencies or agroforestry. But the largest potential is to be found on the demand-side (Popp et al., 2010). The following three main avenues are listed by the Intergovernmental Panel on Climate Change (IPCC): reductions of losses in the food supply chain, changes in human diets toward less animal products, and increased carbon stocks in long-lived wood products (Smith et al., 2014).

Each of these options raises specific issues, as they are associated to profound changes in patterns of production and lifestyles. To investigate how a shift in diet and a reduction in food waste could be efficiently included in climate policies, this paper assesses the potential and barriers based on a review of recent literature and a survey conducted over a sample of 788 respondents living in France. Ways forward towards the reduction of food waste and unsustainable diets are finally sketched. This topic is particularly important for the protein crop sector as it could become a major player in the transition towards sustainable diet by promoting the substitution of meat with leguminous crops.

\section{Mitigation potential of demand-side options}

Calculating the potential for reducing food overconsumption is not straightforward, as there is no consensus either on the adequate level for protein or on the tolerable uppermost intake level. On this matter, the American society for nutrition points out the "misperception" about US protein overconsumption (Rodriguez, 2015). The recommended protein intake of $0.8 \mathrm{~g} / \mathrm{kg}$ body weight/day (Paul 1989) corresponds to a minimum to prevent alimentary deficiencies, but does not ensure optimal health and body composition. WHO, FAO and UNU (2007) indicate that it is unlikely that intakes of twice the recommended level would be associated with any risk. From a health point of view, the origin of proteins-animal or vegetal-matters probably more than the total ingested amount. Even if Inuit traditional livelihood demonstrated that humans can adapt to a diet consisting mainly of meat and animal fat, the fact remains that high consumption of animal products combined with low levels of everyday activity is responsible for a higher incidence of several chronic diseases (Hu and Willett, 1998).

A recent study estimates the demand-side mitigation potential by comparing GHG emissions from the current US food consumption per capita with the following different food diets: traditional Mediterranean, vegetarian and a diet based on the recommended protein intake ( $60 \mathrm{~g}$ of protein per person per day) (Ranganathan et al., 2016). Results showed that the vegetarian diet generated 8.5 tons $\mathrm{CO}_{2}$-eq/cap/year (7.9 from land-use +0.6 from agricultural production), the reducedprotein diet 9.2 tons $\mathrm{CO}_{2}$-eq/cap/year and the traditional

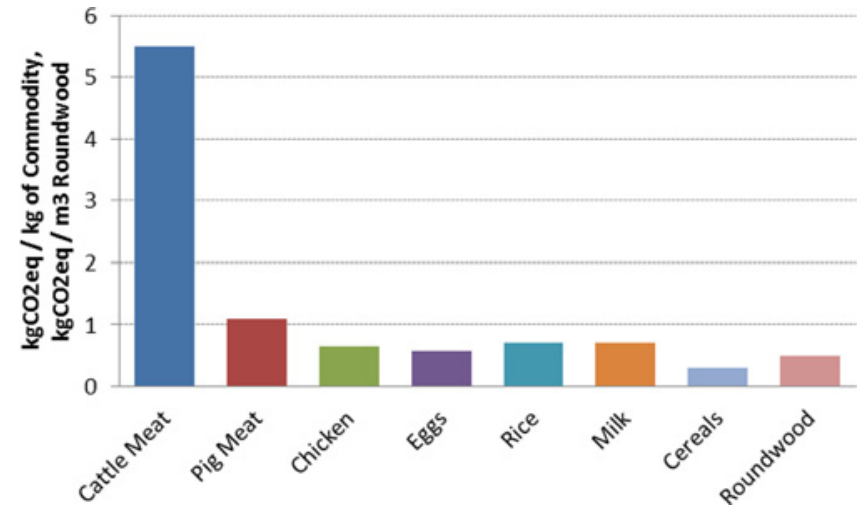

Fig. 1. GHG emission intensities of selected commodities for the decade 2000-2010. Source: Smith et al. (2014), based on Tubiello et al. (2012) and FAOSTAT (2013).

Mediterranean diet 14.7 tons $\mathrm{CO}_{2}$-eq/cap/year, against 16.8 tons $\mathrm{CO}_{2}$-eq/cap/year for the current US diet (15.2 from land-use +1.4 from agricultural production). Emissions reductions of each variant were largely driven by the reduction in ruminant-derived calories, which amounted to $-14 \%$ for the traditional Mediterranean diet, $-50 \%$ for the reduced protein diet and $-94 \%$ for the vegetarian diet. As shown in Figure 1, emission intensities of cattle meat were more than five times higher than for the other types of feedstock. Thus, while beef represents only $3.2 \%$ of the US per cap calories consumption, it accounts for $c a$. half of the emissions (Ranganathan et al., 2016). Given this high emission intensity, Ranganathan et al. (2016) tested two diets shifting one-third of beef calories to either (i) pork and poultry or (ii) legumes as well as a third scenario of beef consumption reduction from $94 \mathrm{kcal} / \mathrm{cap} /$ day to $25 \mathrm{kcal} /$ day/cap. Results showed that substituting beef to legume was more effective than a substitution to pork and poultry, as it reduced the emissions per cap by 1.5 tons $\mathrm{CO}_{2}$-eq/ year compared to a reduction of only 1.2 tons $\mathrm{CO}_{2}$-eq/year for pork and poultry. The third scenario with a net reduction in total consumed calories led of course to the highest emissions reduction with a total of 5.5 tons $\mathrm{CO}_{2}$-eq par cap.

In this study, a substantial share of emission reductions is obtained through a lower use of pasture land area. The impact of a diet shift on cropland area is not completely consistent across the literature. For example, a shift from ruminant meat to pulses resulted in a decrease in cropland area for Stehfest et al. (2009), as they considered a land requirement for beef amounting to $0.6 \mathrm{ha} / 100 \mathrm{~kg}$ of protein against only 0.25 for pulses; for Ranganathan et al. (2016) conversely, a shift from beef to legumes did not affect cropland area. The environmental benefit of sparing grassland area obtained by substituting pork or poultry for beef may have some drawbacks. Gill et al. (2009) pointed out that the efficiency of beef in terms of human-edible return is significantly better than that of pig and poultry; its value is also higher than one, meaning that outputs exceed inputs, as most of pig and poultry feed comes from human-edible feedstock, whilst most of the diet of ruminant livestock is based on human-inedible feedstock (grass and forage-see Fig. 2). Livestock ability to turn human-inedible products into human-edible products may become increasingly important in terms of global food security, as recognized by Gill et al. It should be noted, 


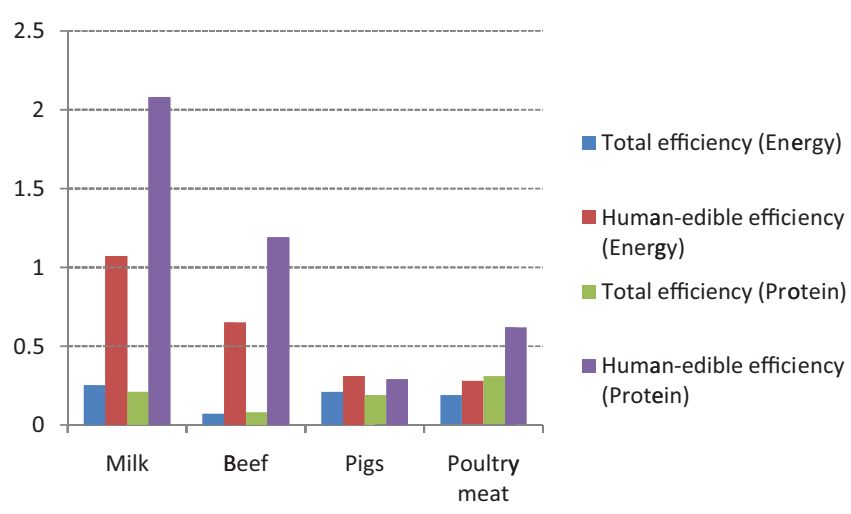

Fig. 2. Efficiencies of different livestock production systems in the USA (outputs of edible energy and protein divided by inputs of energy and protein). Source: Gill et al. (2009).

however, that this is a real benefit for food security only if livestock is raised on lands unsuitable for the cultivation of edible feedstock. On other types of lands, the production of crop protein remains more efficient than that of grass and fodder to produce animal proteins. Finally, the environmental virtues of a substitution between beef and legumes may be mitigated by the lower protein digestibility of legumes, as we may need up to $55 \%$ more proteins from legumes to gain the same metabolic benefit obtained from beef proteins ${ }^{1}$.

The overall mitigation potential of demand-side options appears to be substantial. Indeed, Popp et al. (2010) estimated that a progressive reduction in the share of livestock products $(-25 \%$ per year between 2005 and 2055 , leading thus rapidly to a vegetarian diet) could reduce non- $\mathrm{CO}_{2}$ agricultural emissions by $11 \mathrm{GtCO}_{2}$-eq in 2055. Implementing additional technological mitigation options for all agricultural activities (better water, manure and herd managements, improved N-efficiency, improved feeding practices) would result in a further reduction in emissions by $1.7 \mathrm{GtCO}_{2}$-eq. Hence demand-side mitigation options were found to represent around $85 \%$ of the 2055 total potential of non- $\mathrm{CO}_{2}$ emissions reduction. Based on four dietary scenarios (three variants of partial and complete substitutions of meat by plant proteins + one "healthy diet scenario"), Stehfest et al. (2009) estimated that agriculture and land-use emission reductions related to demand-side mitigation options amount to $31-47 \%$ of total cumulative GHG emissions between 2000 and 2050. As a result, carbon price in 2050 under the $450 \mathrm{ppm}$ stabilization pathway would be reduced by $\approx 45 \%-55 \%$ and the mitigation costs in 2050 reduced by $\approx 55 \%-65 \%$.

Reduction of food losses and waste ${ }^{2}$ represents another key demand-side mitigation option. Estimating the potential of

\footnotetext{
${ }^{1}$ http://www.inspection.gc.ca/food/labelling/food-labelling-forindustry/nutrition-labelling/elements-within-the-nutrition-factstable/eng/1389206763218/1389206811747?chap=7

${ }^{2}$ According to Gustavsson et al. (2011): "Food losses refer to the decrease in edible food mass throughout the part of the supply chain that specifically leads to edible food for human consumption. Food losses take place at production, postharvest and processing stages in the food supply chain (Parfitt et al., 2010). Food losses occurring at the end of the food chain (retail and final consumption) are rather called "food waste", which relates to retailers' and consumers' behavior. (Parfitt et al., 2010)."
}

emissions reduction is however challenging due to the lack of reliable datasets. Based on a mass flow methodology, Gustavsson et al. (2011) estimated that roughly one-third of the food produced was lost globally, which represents about 1.3 billion ton per year. Based on this estimation, FAO (2011) calculated that the energy embedded in food losses and waste throughout the food chain amounted to $c a 36$ ExaJoules/yr, which is more than the total energy consumption in Russia, the third largest energy consumer in the World after USA and China. High-income countries are the largest contributors to food losses and waste, with 58\% of the total embedded energy. The per capita food loss and waste in Europe and North America amount to $280-300 \mathrm{~kg} / \mathrm{year}$, against $120-170 \mathrm{~kg} / \mathrm{year}$ in sub-Saharan Africa and South/Southeast Asia (Gustavsson et al., 2011). Developing and developed countries are also characterized by different patterns of food loss and waste; in the former countries, $40 \%$ of food losses occur at post-harvest and processing levels, while in developed countries, more than $40 \%$ of food losses occur at retail and consumer levels. In terms of percentage of initial production, fruits and vegetables are the most lost or wasted commodities $(>50 \%$ in most regions of the world), while dairy products are the least lost or wasted ones $(\approx 10 \%$ in Europe and Industrialized Asia, $\approx 20 \%$ in other regions) (Gustavsson et al., 2011).

By compiling total food waste across different stages of the UK food supply chain, Parfitt et al. (2010) showed that households are the largest contributors to food waste. According to this study, $64 \%$ of the food wasted by households is avoidable, $18 \%$ is potentially avoidable and $18 \%$ is unavoidable ${ }^{3}$. The most often cited reasons for throwing food away are the following: "food is not used in time" (was past a "use by" limit, smelt or tasted bad) and "too much is cooked, prepared or served" (this category also covers food that was damaged during processing) (Parfitt et al., 2010).

Parfitt et al. (2010) also identified the following three interrelated global drivers of post-harvest losses: (i) urbanization and the contraction of the agricultural sector may increase the generation of food waste by extending food supply chains and disconnecting consumers from how food is grown; (ii) dietary transition implies a diversification of food consumption towards vulnerable, shorter shelf-life items; (iii) increased trade globalization could open up opportunities, such as driving investments in storage, transport and distribution infrastructures, while representing a threat by increasing the supply of inexpensive food, thus spurring food wasting behaviours.

Another proposed option to reduce our meals' environmental footprint is to eat more local and seasonal food. Carlsson-Kanyama (1998) showed that a vegetarian meal with imported rice and tomatoes in addition to dry peas emits more than a meal containing only domestically produced food of both animal and vegetable origin $\left(\approx 800 \mathrm{~g} \mathrm{CO}_{2}\right.$-eq against $\approx 400 \mathrm{~g} \mathrm{CO}_{2}$-eq). However, this finding is more largely

\footnotetext{
${ }^{3}$ Parfitt et al. (2010) define avoidable and unavoidable waste as follows: Avoidable and potentially avoidable food waste refers to food and drink thrown away that was at some point edible or potentially edible (bread crusts, potato skins). Unavoidable waste refers to food preparation that is not, and has not been, edible under normal circumstances.
} 
explained by methane emissions from rice farming and nitrous oxide emissions from fertilization of tomatoes, than by carbon dioxide emissions from transports. Overall, Carlsson-Kanyama (1998) concluded, based on the lifecycle analysis of 6 products (pork, carrots, tomatoes, potatoes, rice and dry peas), that transportation is a minor contributor to the total emissions of greenhouse gases compared to other stages of production, such as storage, pig rearing and rice farming, representing about 5\% of GHG emissions of Tomatoes, Rice and Dry Peas, about $15 \%$ for carrots and $30 \%$ for potatoes.

Weber and Matthews (2008) came to a similar conclusion based on US input-output accounts of household expenditure and food availability from U.S. Department of Agriculture statistics. Although the total freight (from production to retail) to meet food demand in the United States in 1997 was $1.2 \times 10^{12} \mathrm{tkm}$, representing approx. $6500 \mathrm{~km} / \mathrm{kg}$ of food, transportation as a whole represented only $11 \%$ of life cycle GHG emissions associated with food production. Weber et al. emphasized thus that "shifting less than one day per weeks' worth of calories from red meat and dairy products to chicken, fish, eggs, or a vegetable-based diet achieves more GHG reduction than buying all locally sourced food. "

\section{Barriers}

Barriers to the adoption of demand-side mitigation measures are mainly of an economic, institutional and socio-cultural nature. Few technical obstacles are reported in the literature. These technical obstacles concern for example some potential progress in packaging to further increase shelf life (Parfitt et al., 2010).

The livestock sector represents $30 \%$ of the agricultural GDP in the developing countries, and about $40 \%$ of global agricultural GDP (World Bank, 2009). This sector is organized in long market chains that employ at least 1.3 billion people globally and directly supports the livelihoods of 600 million poor smallholders in the developing world (Thornton, 2010). The growth of the livestock sector is heavily dependent on a sustained demand. Incentives to consume livestock products thus remain strong, in the form of advertisements, relatively cheap prices or larger portions sold. Furthermore, the electoral weight of the agricultural sector in many countries does not encourage governments to support policies that may harm this political group.

Underinvestment in storage, transport and distribution infrastructures in developing countries is often cited as an important economic barrier to the reduction in food waste. It is however difficult to assess to what extent this is a major obstacle, as there are many instances of relatively simple and inexpensive technologies providing effective solutions substantially reducing post-harvest food losses (Parfitt et al., 2010). Economic obstacles to the adoption of vegetarian or reduced animal protein diets are not seen as relevant since they are cheaper than a conventional diet (Faber et al., 2012). As previously mentioned, the extension of urban lifestyles may limit the adoption of environment friendly food diets and more efficient food waste management practices. In addition, the lack of adequate supplies of climate-friendly food in low income urban and rural areas, commonly referred to as food

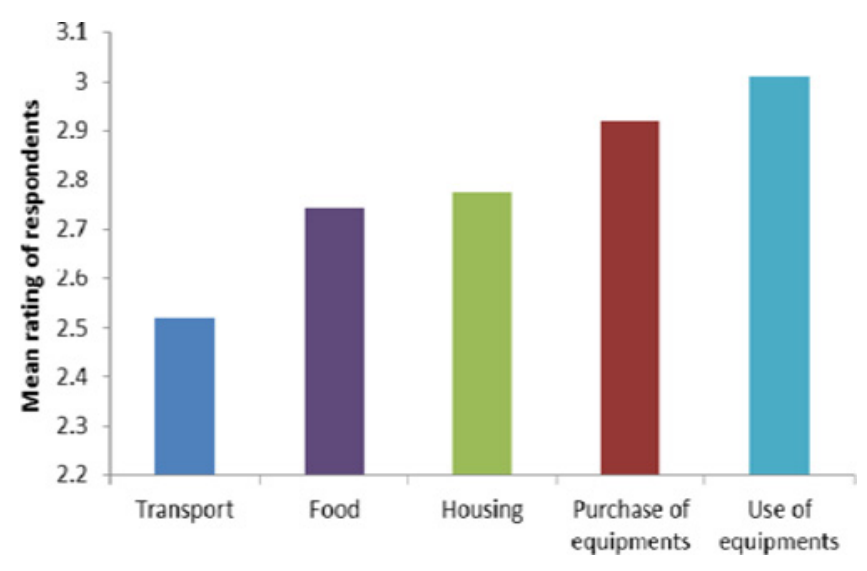

Fig. 3. Willingness to make further effort to reduce emissions in five areas (scale: $0=$ zero willingness, $4=$ high willingness). Source: Authors.

deserts, could constitute a significant barrier to demand-side mitigation measures.

Overall, societal barriers are considered to be less stringent than individual ones as demand-side mitigation strategies are intrinsically linked to personal choices, which themselves depend on knowledge, culture, habits and tastes. To get a better grasp on this issue, we took the census of the individual barriers most frequently cited based on a literature review and submitted them in the form of a web survey to a sample of 788 people living in France (yielding an margin of error by $4.6 \%$ ). Results were adjusted to be representative of the main characteristics of the French population in terms of age, place of residence, socio-professional categories and owner/tenant status. Because obtaining a sufficient number of answers from workers was difficult, results for this socio-professional category had to be highly adjusted and are for this reason probably biased.

Before considering barriers, we asked the respondents to assess their willingness to reduce GHG emissions in the following five areas: transport, food, housing, purchase of equipment and use of equipment. For each question, they were asked to grade their action (or willingness to act) as (i) none, (ii) weak, (iii) middle, (iv) high and (v) "exemplary behaviour". Answers were translated into numerical terms from 0 to 4, assuming a linear relation between qualitative and quantitative assessments. In other words, the range of outcomes is quite arbitrary, and only the ranking of actions is meaningful. Respondent were also asked to grade their level of information about climate change mitigation. Wellinformed respondents were selected on this basis.

After transport, food appeared to be the area where respondents were the least willing to take actions to reduce their emissions (see Fig. 3). Food was however also the area where people thought they made the most efforts (see Fig. 4); respondents may thus have judged they had less room to further decrease their emissions. Even though these are statements subject to personal assessment, the relatively high level of action in the food area is corroborated by the rapid increase in consumption of organic food, and the noticeable decrease in meat consumption in France. To evaluate the accuracy of personal assessments, we undertook a cross-check by comparing the relative level of action reported by 


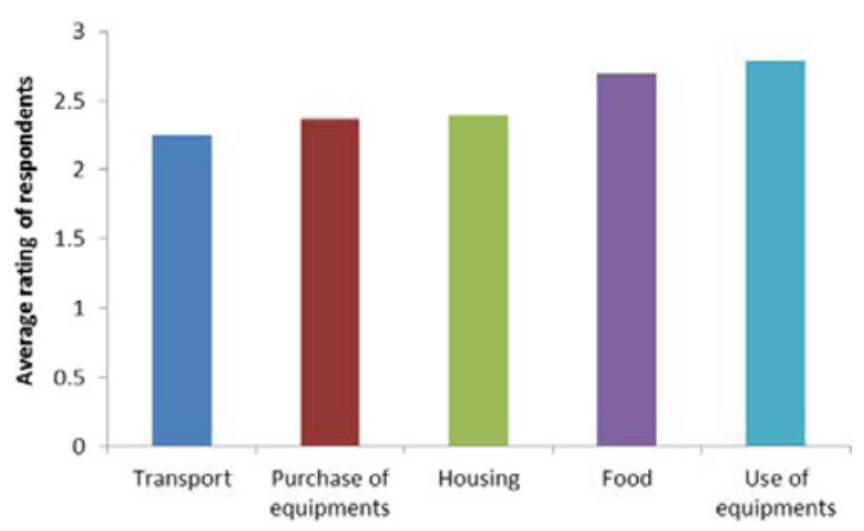

Fig. 4. Actual effort to reduce emissions in five areas according to respondents (scale: $0=$ no effort, $4=$ high effort). Source: Authors.

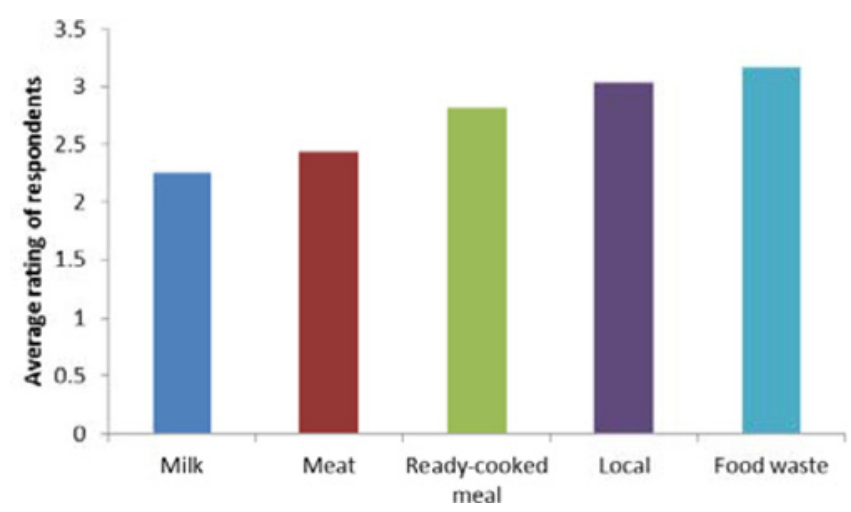

Fig. 5. Favoured action to reduce emissions in the food area (scale: 1 = zero willingness, 4 = high willingness). Source: Authors.

respondents with the relative level of emissions reported by respondents. In doing so, we found that food is the area with the least discrepancies between answers on action and emissions levels, thus giving us some confidence in respondents' self-evaluations.

To reduce their emissions in the food area, respondents favour the reduction in food waste over eating more local food and less ready-cooked meals (see Fig. 5). On the contrary, respondents appear to be more reluctant to reduce meat and milk consumption. Our survey reveals that this reluctance is mainly due to health considerations and to the belief that proteins from animal products cannot be substituted by other types of food (see Fig. 6). This result is consistent with the findings of Dibb and Fitzpatrick (2014) and Barr and Chapman (2002). As expected, this argument was much less cited by well-informed respondents (see definition above and blue bars in Fig. 6). Pleasure and taste were also frequently cited barriers along with habits and cultural reasons, both by the entire sample and well-informed respondents. This importance of pleasure and taste is confirmed by Lea et al. (2006) and Graça et al. (2015). Meat eating is indeed rooted in many traditions, to the extent that we often consider that the origins of human intelligence are linked to the nutritional qualities of meat. It has been showed though, on the basis of research on chimpanzees, that the development of human brain is more probably due to the cognitive abilities that were needed for the strategic sharing of meat within the group (Stanford, 1999). It is also interesting to note that the social constraint, which refers

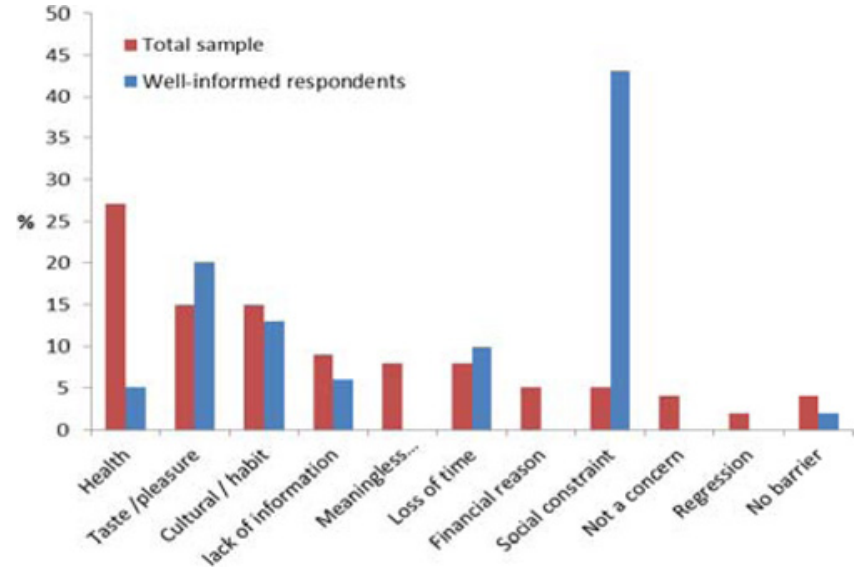

Fig. 6. Frequently cited barriers to emissions reduction in the food area (in $\%$ of the total cited barriers). Source: Authors.

mainly to the feeling of pressure from the social group, is by far the most frequently cited barrier by well-informed respondents. Meat eating, as part of our evolutionary heritage, is surrounded by a special symbolic signification, such as affluence, wellbeing, satiety and contentment (Smil, 2002), which may generate some social pressure.

\section{Ways forward}

In the second half of the 20th century, several political initiatives have been taken to reduce food waste. This objective was part of the mandate of the Food and Agriculture Organization of the United Nations (FAO), when it was created in 1945. In 1975, at the VIIth Special Session of the United Nations General Assembly, a resolution was passed calling upon member states to reduce post-harvest food losses by 50 percent by 1985 . FAO's programme on prevention of food losses was established in 1977 to accompany member states in the design and implementation of an effective plan of action. A total of 108 projects had been financed by 1982 , mainly with the objective of facilitating coordination and research. In spite of a 30.2 million US\$ investment in these projects, there is no report of any actual progress towards the 50 percent target (Parfitt et al., 2010).

More recently, efforts to combat food waste have been mainly undertaken by the civil society in the following ways: promotion of "ugly" fruits and vegetables, supermarket for expired products in Denmark, networking between structures with food surplus and charitable associations in Great Britain and California, collaborative actions such as shared refrigerators, etc. Governments, for their part, have only recently taken measures under civil society pressure. France has recently adopted a bill including the following measures: waste prevention, use of unsold products as gift or for processing, waste valuation as animal feed, compost or as energy through methanizing. Efforts at the European level remain for the moment mostly symbolic in the following manner: relaxing the rules of calibration and presentation for 26 fruits and vegetables, publication of reports and surveys and organization of the international year against food waste in 2014. A noticeable exception to the limited governmental efforts to support climate-friendly food relates to the recent Chinese 
initiative to reduce meat consumption by $50 \%$ before 2030 . The translation of this initiative into effective political action is, however, not specified for the moment.

Strategies for reducing food waste in developed and developing countries should be designed based on different logics. In developing countries, the emphasis should be placed on investment in agricultural infrastructure, technological skills and knowledge, storage, transport and distribution (Parfitt et al., 2010). On the other hand, policies in developed countries should focus on retailers and consumers, through, for example, food labelling to increase awareness of food waste's impact on the environment (Parfitt et al., 2010).

There is currently no policy aiming to orient consumer's choice towards less meat-intensive diets. Wirsenius et al. (2011) studied the impact of a GHG weighted consumption tax equivalent to $60 €$ per ton $\mathrm{CO}_{2}$-eq on the following products: ruminant meat, pork, poultry, eggs and dairy products. Their results show that such a tax scheme would lead to a net reduction of 32 million ton $\mathrm{CO}_{2}$-eq, which corresponds to a $7 \%$ reduction of emissions in EU agriculture. The emissions reduction results from a shift in food consumption from ruminant meat, milk and eggs to pig and poultry meat. Note that this study did not consider any possible substitution between animal and vegetal proteins, which could further increase emission reduction potential.

However, a carbon tax on food products could be socially difficult to implement. Wirsenius et al. (2011) calculated that a GHG tax corresponding to $60 €$ per ton $\mathrm{CO}_{2}$-eq would increase the price of ruminant meat by $1.4 €$ per kilo. This would thus restrict the consumption of ruminant products to the richest part of the society, those for whom food expenditures are only an insignificant fraction of their budget. To avoid targeting the poorest, who are also those with the lowest emission per capita, Ranganathan et al. (2016) proposed a holistic approach relying on the following four principles: (i) minimize disruption by minimizing changes for example in taste, look or texture; (ii) "sell" a compelling benefit such as health or affordability, (iii) maximize awareness by increasing the availability and visibility of sustainable food; (iv) evolve social norms by informing people about the environmental impact of our food choice and make alternatives socially desirable.

\section{Conclusion}

There is a strong consensus in the existing literature about the high mitigation potential of AFOLU demand-side mitigation measures, higher, in particular, than that of supply-side mitigation options. Shifting diets towards less animal products and reducing food losses appear to be the most effective avenues, while eating more local and seasonal food would bring only marginal environmental benefits. However, to guarantee that these measures do not imply a reduction in protein intake, these estimations should consider both caloric and protein units, and take into account digestibility differentials between protein sources. In spite of this large potential, commitment to take action is however not apparent both from national governments and individuals, the latter being relatively reluctant to eat more sustainably, preferring to reduce their emissions in other areas such as housing or equipment. Governmental initiatives remain, for their part, isolated and mostly symbolic.
A high potential for emissions reduction is within reach. The challenge is now to find the correct incentives to guide consumers towards sustainable food. Holistic approaches aiming at minimizing perceived costs and maximizing perceived benefits are probably a promising strategy to make demand-side mitigation options more acceptable. Considering the overall cost of climate policy could also help incentivize public and private actors, as limited efforts on food consumption, such as a partial substitution of meat by plant protein, could significantly reduce mitigation costs.

Acknowledgements. The authors wish to thank Patrice Dumas and Jean Vettraino for their valuable comments on previous versions of this article, and Philippe Chatelet for his editing of English language in the paper.

\section{References}

Barr SI, Chapman GE. 2002. Perceptions and practices of self-defined current vegetarian, former vegetarian, and non-vegetarian women. J Am Diet Assoc 102 (3): 354-360.

Carlsson-Kanyama A. 1998. Climate change and dietary choices how can emissions of greenhouse gases from food consumption be reduced? Food Policy 23 (3-4): 277-293.

Dibb S, Fitzpatrick I. 2014. Let's talk about meat: changing dietary behaviour for the 21 st century. London: Eating Better.

Faber J, Schroten A, Bles M, Sevenster M, Markowska A. 2012. Behavioural climate change mitigation options and their appropriate inclusion in quantitative longer term policy scenarios. Delft: CE Delft.

FAO. 2011."Energy-smart" food for people and climate. Issue Paper. Rome: FAO, 78 p.

FAOSTAT. 2013. FAOSTAT database. Rome: Food and Agriculture Organization of the United Nations. Available at: http://faostat. fao.org/.

Gill M, Smith P, Wilkinson JM. 2009. Mitigating climate change: the role of domestic livestock. Animal 4 (3): 323-333.

Graça AJ, Oliveira A, Calheiros MM. 2015. Meat, beyond the plate: data-driven hypotheses for understanding consumer willingness to adopt a more plant-based diet. Appetite 1 (90): 80-90.

Gustavsson J, Cederberg C, Sonesson U, van Otterdijk R, Meybeck A. 2011. Global Food Losses and Food Waste. Extent, Causes and Prevention. Rome: Food and Agricultural Organization of the United Nations, $29 \mathrm{p}$.

Hu FB, Willett WC. 1998. The relationship between consumption of animal products and the risk of chronic diseases: a critical review. Cambridge, MA: Harvard University Medical School.

Lea EJ, Crawford D, Worsley A. 2006. Consumers' readiness to eat a plant-based diet. Eur J Clin Nutr 60: 342-351.

$\mathrm{Ng} \mathrm{M}$, Fleming T, Robinson M, et al. 2014. Global, regional, and national prevalence of overweight and obesity in children and adults during 1980-2013: a systematic analysis for the Global Burden of Disease Study 2013. Lancet 384 (9945): 766-781.

Parfitt J, Barthel M, Macnaughton S. 2010. Food waste within food supply chains: quantification and potential for change to 2050. Phil Trans $R$ Soc Lond B Biol Sci 365 (1554): 3065-3081.

Paul GL. 1989. Dietary protein requirements of physically active individuals. Sports Med 8 (3): 154-176.

Popp A, Lotze-Campen H, Bodirsky B. 2010. Food consumption, diet shifts and associated non- $\mathrm{CO}_{2}$ greenhouse gases from agricultural 
production. Glob Environ Change 20 (3): 451-462. Governance, Complexity and Resilience.

Ranganathan J, Vennard D, Waite R, Searchinger T, Dumas P, Lipinski B. 2016. Shifting Diets for a Sustainable Food Future. Working Paper, Installment 11 of Creating a Sustainable Food Future. Washington, DC: World Resources Institute.

Rodriguez NR. 2015. Introduction to protein summit 2.0: continued exploration of the impact of high-quality protein on optimal health. Am J Clin Nutr 101 (6): 1317S-1319S.

Smil V. 2002. Eating meat: evolution, patterns, and consequences. Popul Dev Rev 28 (4): 599-639.

Smith P, Bustamante M, Ahammad H, et al. Agriculture, Forestry and Other Land Use (AFOLU). In: Edenhofer O, Pichs-Madruga R, Sokona Y, et al., eds. Climate Change (2014): Mitigation of Climate Change. Contribution of Working Group III to the Fifth Assessment Report of the Intergovernmental Panel on Climate Change. Cambridge, United Kingdom/New York, NY, USA: Cambridge University Press, 2014.

Stanford CB. 1999. The hunting apes: meat eating and the origins of human behavior. Princeton: Princeton University Press.

Stehfest E, Bouwman L, van Vuuren DP, den Elzen MGJ, Eickhout B, Kabat, P. 2009. Climate benefits of changing diet. Clim Change 95 (1): 83-102.
Thornton PK. 2010. Livestock production: recent trends, future prospects. Phil Trans R Soc Lond B Biol Sci 365 (1554): 2853-2867.

Tubiello F, Salvatore M, Rossi S, Ferrara A. 2012. Analysis of global emissions, carbon intensity and efficiency of food production. Energia Ambiente e Innovazione Anno 2012: 87-93. Available at: http://www.enea.it/it/produzione-scientifica/EAI/anno-2012/n.4-5-luglio-ottobre-parte-I/analysis-of-globalemissions-carbon-in tensity-and-efficiency-of-food-production.

Weber CL, Matthews HS. 2008. Food-miles and the relative climate impacts of food choices in the United States. Environ Sci Technol 42 (10): 3508-3513.

Wirsenius S, Hedenus F, Mohlin K. 2011. Greenhouse gas taxes on animal food products: rationale, tax scheme and climate mitigation effects. Clim Change 108 (1): 159-184.

WHO, FAO, and UNU (World Health Organization, Food and Agriculture Organization of the United Nations, and United Nations University). 2007. Protein and amino acid requirements in human nutrition. Geneva: WHO. Accessible at: http://www.who.int/ nutrition/publications/nutrientrequirements/WHO_TRS_935/en/.

World Bank. 2009. Minding the Stock: Bringing Public policy to Bear on Livestock Sector Development. Report No. 44010-GLB. Accessible at: http://siteresources.worldbank.org/INTARD/ Resources/FinalMindingtheStock.pdf.

Cite this article as: Brunelle T, Coat M, Viguié V. 2017. Demand-side mitigation options of the agricultural sector: potential, barriers and ways forward. $O C L, 2017,24(1) \mathrm{D} 104$. 